\title{
Rational Thinking on Construction of Excellent Study Style in Local Undergraduate Universities
}

\author{
Jianhua Deng, Naizhu Huang* \\ Institute of Mathematics and Finance, XiangNan University Hunan Chenzhou, 423000 \\ huangnzh@163.com
}

Keywords: local colleges and universities; construction of study style

\begin{abstract}
Style of study is the "essence" of a school, which is an important guarantee for the growth of students. At present, the problems of the study style of local colleges and universities are becoming more and more serious, which has seriously restricted the sustainable development of college students. The main factors causing the formation of bad style of study in local colleges and universities are as follows: The gap between ideal and reality leads to the decrease of students' desire for knowledge, the rising of the theory that "schooling is useless" stifled the learning interest of college students, the social material temptation resulted in the utilitarian learning motivation and some teachers' non-strict scholarship caused the students' study-weariness. The main path of constructing excellent study style in local colleges and universities is as follows: Promote research study to guide students to devote time and energy to scientific research; guide students to make career planning to enhance learning motivation of college students; strengthen the education of responsibility to promote the formation of learning atmosphere.
\end{abstract}

\section{INTRODUCTION}

Style of study is the "essence" of a school, having both broad and narrow senses. The style of study in broad sense refers to the sum of the style of students' learning and researching, the style of teachers' teaching and academic management, the style of teaching management personnel's educational inspection and management, and the style of school leaders' school running and guidance (Chen, 2014). The style of study in narrow sense refers to the external performance and reflection on the study of students' internal characters such as learning purpose, learning attitude, learning methods, learning spirit and others (Liu, 2011). Strengthening the construction of study style and forming a good style of study are proposed in the educational management of students, which refers to the style of study in narrow sense. It aims to cultivate students' good learning habits and promote the all-round development of college students' moral, intelligence, body and virtue with excellent learning atmosphere.

\section{ANALYSIS OF CURRENT SITUATION OF STUDY STYLE CONSTRUCTION IN LOCAL COLLEGES AND UNIVERSITIES}

Confucius's saying that "Wide learning, detailed questioning, deliberate thinking, clear distinguishing, effective conducting” (Zi, 2014), actually is the classic definition of the study style in universities, which is used by the local colleges and universities to investigate the study style of college students, finding the following performances.

\subsection{No Wide Learning, Only for Exam}

Students go to college for the "professional studies", at the same time, they still should learn the knowledge of other subjects extensively and expand their own knowledge constantly, trying to strive to attack the "professional jade" by using "the stone of other mountain". As the science master, Qian Xuesen once said: "Would that I could have read the Chairman Mao's "Theory of Contradiction", I would be able to publish the monograph "Engineering Cybernetics" at an early date." It is clear to us that broad knowledge is more conducive to expanding the dimensions of 
thinking to solve the professional problems. Ancient mottos like "Reading is always beneficial", etc, all confirmed the importance of a wide range of learning from side. However, some local college students do not have interest in a wide range of learning, but idle all day long, being free from learning and playing in love. For their professional courses, they just stay in the state of "listening in class and picking up the book after class”, which couldn't be integrated into knowledge system. They almost never read the books unrelated to their professional, so with the narrow vision, they can not effectively integrate the knowledge of various disciplines and can not improve the ability to solve problems.

\subsection{No Questioning in Detail, Avoiding Exploration}

College students in colleges and universities should be like a sponge to grasp all opportunities for learning to acquire and reserve professional knowledge to improve their academic level, while they also should explore in the professional field bravely to abandon the old and bring forth the new so as to shoulder the historical mission of realizing the great rejuvenation of Chinese nations bestowed by the times. However, in real life, more and more college students are with the following performances: For the professional knowledge, they only know what it is, but do not know why. They learned nothing from the class because they didn't listen to teacher's explanation, and they got nothing after class because they didn't study deeply and digest the knowledge effectively. Because they studied without thorough understanding, they couldn't discovery and explore the problems when learning. Without the spirit of exploration that "insist on getting to the bottom of the matter", their academic level can never be got leapfrog development. In the process of avoiding exploration, the students waste the best time of youth without hesitation, just like A Dou with the thought that "being happy here without missing the country", which is a sadly sigh.

\subsection{Thinking Poorly and Do Things Carelessly}

As the reserve talents of science and technology, college students should shoulder the important task of promoting social development and scientific and technological progress with indomitable spirit of "digging" and "research". "Digging" is to focus on a certain academic issue to delve into the way to resolve it and constantly improve our own academic level. "Research" is to be absorbed in an academic problem to think about the ins and outs of it over and over again, trying to see the essence through the phenomenon to obtain the truth, thus becoming enlightened at once to discovery and innovate something. Learning is to achieve not only "What" but also "Why", and students should treat academic issues with in-depth thinking, but without the overall acceptance of "brings the principle”. The performance of college students' poor thinking has the following three kinds: The first is that the students can't think because of insufficient knowledge and ability, namely, " the spirit is willing, but the flesh is weak "; the second is that the students are afraid of thinking because of the fear of monotonousness of learning, namely, restricting their own activities to a designated area or sphere; the third is that the students are unwilling to think because they make no attempt to make process, " step on the watermelon skin and slip to where it slip ".

\subsection{Do not Tell the Truth from the False and Lap up Information without Thinking}

University is the frontier of theoretical innovation and scientific and technological breakthroughs and should be a place for intense academic debate. A university without debate has no vitality, and rigid thinking can only be "a pool of stagnant water without any ripple. Remember the narration when lying was held every night in college dormitory, where the students often presented their own opinions on some academic problems, and both sides of the argument were flushed quarreling with each other, while they were unwilling to stop the debate until they figured out the problem, in fact, this is a speculation on the knowledge. Two thousand years ago, Confucius often used the ways of argument and speculation to educate students to make students understand all sorts of things. Confucius worried that the student who "was a yes-man” and didn't ask question couldn't become a useful person. However, the progress of human civilization has changed the college students into the "Phubber", who indulged in online games or chatting online all the time and delayed their own learning works. The biggest effect it brought is that when learning the professional knowledge, the students have to adopt the attitude that read hastily and without thinking to accept all knowledge without distinguishing the good from the bad. 


\subsection{Poor Practice and Separation of Learning and Practice}

"Hu-xiang spirit, study for the purpose of application", the purpose of learning is to solve practical problems in the process of practice. Our school motto is "Virtue, Knowledge, Innovation, Practice", which clearly tells students that learning focuses on practice and they need to check their abilities of adopting knowledge to solve actual problem through practice. When studying and living in school, college students should be able to study in the way of linking theory with practice, and develop the study style of linking theory with practice, namely, lively learn lively use. This is not only the needs of transformation and development of school to serve local economy, but also the needs of the development of college students. However, currently, the serious separation of theory and practice has happened to some college students. The students only satisfied with learning theories in textbooks and excluded the learning of social practice, while the students only learn the prescribed professional courses and just need to get high scores and even pass on the line in the academic examination. Therefore, for the social practice course and the social practice in holiday, only few students really go with the subject, and only few teams conduct the down to earth investigation. They are often in the fun and see the scenery, but do not watch "what is what", so the social research is of course "nothing is gained with an empty head ".

\section{FACTORS' ANALYSIS OF FORMATION OF BAD STUDY STYLE IN LOCAL COLLEGES AND UNIVERSITIES}

The construction of excellent study style is related to the quality of personnel training in colleges and universities. After graduating, whether college students can be employed lies in students' true skill and genuine knowledge and the ability of solving practical problems. In other words, whether college students can be successful or not, which is closely related to the style of study. At present, internal and external factors restricting the formation of good study style in local colleges and universities are as follows:

3.1 The Gap Between the Ideal and The Reality Knocks the Student's Desire for Knowledge

After entering the university, young people embracing the lofty ideal found that there was a big gap between the present situation of university with their expectations in the aspects of hardware and software facilities, learning atmosphere, academic atmosphere and so on, and then the feeling of being abandoned by life arose with strong psychological gap. Psychological imbalance brought by psychological gap expanded rapidly, which seriously dampened the pursuit of progress of college students. For the students who were admitted to university through professional adjustment because of unsuccessful college entrance examination and were forced to choose universities by teachers and parents with their own experience, the result of the "halo effect" caused a fatal psychological blow and made their heart almost collapse. They have been not interested in school and professional, moreover, the gap between ideal and reality resulted in unexpected psychological depression. Lack of desire for learning weakened the goal, and learning in class is purely in order to cope with roll call, namely, "working without efforts”, so even skipping classes is not surprising.

\subsection{Rise of "Schooling is Useless" Stifles the Learning Interest of College Students}

College education is the best path for young talents who passed college entrance examination to obtain professional and systematic training. After entering the university, the college students should learn all kinds of cultural knowledge thirstily in order to "learn various skills" and devote to the construction tide of Chinese nation's great rejuvenation. However, our country is an acquaintance society and some phenomenon such as "tailor-made position”, "nepotism” would exist inevitable when employing workers, resulting in the emergence of the strange phenomenon of "father competition". It caused that college students are full of vigor when "learning in the game" and can soak in network and game for the whole night; while for the main business in college life professional learning, they feel dizzy and sleepy. Because they have determined that academic achievement is not equal to employment and personal expectations anyway, they prefer to live a comfortable life leisurely. Under the catalysis of the theory of "schooling is useless", the negative learning atmosphere has the base for existence and the learning interest of college students has been reduced with the passage of time. 


\subsection{Social Material Temptation Results in the Obvious Utilitarian Learning Motivation}

"A book holds a house of gold, a book holds a beautiful woman", originally reading is the only way for intellectuals to change their fate, so scholars are all walking on learning avenue that "the road is long and narrow without boundary, and I will be up and down to seek the sunshine in my heart" with the hope that " fame fills the land once honors are won". However, the current society is full of materialistic life with scene of debauchery, "drinking with big bowl and eating large pieces of meat" let a person move with the calm serenity of a god, "fragrant carriage and precious horse -the beautiful carriage of women" makes people get the blood pumping. Moreover, the internet is preaching that a "seller in Wechat" earned the net profit of one hundred thousand yuan for one month, and an agent of some product can earn ten thousand yuan for one month, which looks like "pie in the sky" and as long as you enter this circle, "it is difficult to not get rich". Some students put their learning interest into the development of "e-commerce" and "selling in Wechat" in order to meet their material needs, while they only study and explore the knowledge that can bring economic benefits, and skip the professional courses that cannot bring economic benefits.

\subsection{Non-Strict Scholarship of Some Teachers Results in the Rise of Students' Weariness}

Teachers can improve the civilization of human society through the spread of knowledge. Therefore, teachers should be a model of others to spare no effort in researching the educational supervision and guide students to devote their time and energy to learning. In this way, once the error of students' learning attitude emerges, students will be back on track and work hard to obtain success under the call of the conscience. However, some teachers driven by market economic profit have the unhealthy mentality that "future is seeking for money", which breaches the professional requirements that "teacher should impart knowledge and explain difficult problems". They didn't constantly strive for perfection in scholarship and couldn't achieve that "as knife and file make the bone smooth, so jade is wrought by chisel and stone -- help each other in study", namely, "persons in the dark cannot light the way for others". They turned the major works of imparting knowledge and educating people into the sideline, and their images that "being wealthy in knowledge to investigate phrase” crashed to the ground. These teachers without rigorous scholarship and good teaching could not transfer knowledge to students, giving birth to students' unhealthy atmosphere of weariness and truancy.

\section{CONSTRUCTION OF STUDY STYLE IN LOCAL APPLIED UNIVERSITIES}

In addition to world-class academic masters, first-class students, first-class teaching and research facilities, first-class academic achievements, etc, the key point of the world first-class university lies in the fact that they have good style of study (Su, 2014), and the students living in it are like "the fleabane growing in the field of hemp becomes straight itself without support”, namely, consciously growing for high-end talent. Schools should use macro-control means to fully mobilize the enthusiasm of teachers and students into the construction of good style of study, and ensure that the cultivated high-quality graduates will serve the local economic development.

\subsection{Promote Research Learning and Guide Students to Devote Their Time and Energy to} Scientific Research

College students have to study (explore) the problem with orientation, and cannot read the dead book in the way of dead reading, which is easy to change a person into a "robot" with high score and low ability. Without the book, they would be like the blind man feels the elephant-taking a part for whole, thus it is certainly not possible to forge ahead. Promote research learning, which is the only way for the development of undergraduates. "Lively Learn lively use" and "study for the purpose of application" require people to make full use of knowledge to solve practical problems. Research study is to require students to actively think about the problem in the learning process, and then explore the way to solve the problem. In this way, in order to find a solution to the problem, the students will make full use of the knowledge learned before, try their best to decompose and reconstruct the problem, and ultimately solve the problem successfully, thus improving their academic ability. In the exploration process, college students would digest and bring the learned knowledge together, and naturally the learned knowledge is constructed as a knowledge system 
with random control by them, which greatly strengthens the professional knowledge to promote students to be the talents. Firstly, the school should fully grasp the top-level design of students' education and training scheme, adopt policy guidance to require students to devote time and effort to both scientific research and exploration, as far as possible provide the project support for college students, and relieve students from financial pressure because of project research so as to devote themselves to the research. At the same time, set up a typical model of research learning among students to encourage students to explore bravely. Secondly, the professional teachers should guide and inspire students to do subject research in teaching and usual communication, expand students' thinking, arouse students' enthusiasm of scientific research, stimulate students' desire for exploration and determination to tackle tough. At the same time, when setting up the scientific research team, teachers should bring the students with similar research direction into the team, and let them feel the joy of doing scientific research to understand that scientific research is not too high to be reached. Thirdly, counselors should always comment on the present situation of research study in classroom, release positive energy, and inspire all the students to study seriously and explore actively to lead the trend of the times tide.

\subsection{Guide Students to Make Career Plan and Strengthen Students’ Learning Motivation}

Some college students have no clear learning objective and deep understanding of the importance of learning for job candidates, whose deepest reason is that they do not know after graduation they will face with job market selection that "survival of the fittest" with narcissism in the halo of "God's favored one", and immerse themselves in the "sweet days" of freedom without their parents' supervision. However, with the social and economic downturn, the jobs which can be provided for students are seriously insufficient and are in a serious imbalanced state that "there are too many (Buddhist) monks and too little gruel -- cannot meet the needs of the people". The people without "ability" would be snubbed at all place in the job hunting process and eventually reduce to "moonlight clan" and "Boomerang Kids". Colleges and universities should guide college students to make career planning, fully understand the employment situation, and arrange the scientific and reasonable university life, giving birth to a strong learning motivation. Firstly, when entering university the freshmen should be educated with employment situation and be aware of employment situation. The education of employment situation in college when students enter the school makes them realize soberly that they must have solid professional knowledge and skills so as to emerge as the best talent from the army of employment, and when going to work, they could skillfully deal with the affairs in the professional field, even could work creatively so as to solve the technical problems encountered in the working place. Secondly, set up a team of excellent career guidance teachers to systematically guide students to make tailored career planning. The teacher with unique guide experience should be selected as the speaker of "Employment Guidance Course", and this course should be offered in the first grade, the second grade, the third grade and so on, which would help the students under the guidance of teachers to make feasible medium and short term planning with the combination of their own reality, while they could make a good plan of their learning and life and achieve their goals step by step according to the plan. The third is to set an example which students can effectively imitate. The school should often invite famous alumni to make lectures, introduce their successful experience, and effectively explain the present demand for talents to make the students have the most intuitive understanding, thus devoting the time and effort to professional learning.

\subsection{Strengthen the Education of Responsibility and Promote the Formation of Learning Atmosphere}

"Everyone is responsible for the fate of his country." This sentence reveals that everyone in the society is responsible for the rise and the fall of the country. Liang Qichao once said: "Juvenile wisdom, the country is wisdom; juvenile rich, the country is rich; juvenile strong, the country is strong." The contemporary college students should combine their own development with the prosperity of the motherland, and be brave to take on the great responsibility of national rejuvenation. The first is to strengthen the education of Chinese modern history, enhance the sense of responsibility of college students. Through the education of Chinese modern history, remember 
the lessons of "backward will be beaten" and" reading for the rise of China ". From Chinese modern history, the Chinese nation suffered humiliation and was forced to sign a series of unequal treaties under the threat of Western powers' solid ships and advanced cannons. Under the leadership of the Communist Party of China, China realized the great national liberation and embarked on the socialist road. With the guidance of reform and opening up, China has become the world's second largest economy, and young students should learn professional knowledge, gallop in all walks of life, and promote socialist modernization construction. The second is to strengthen the education of international situation and enhance the sense of responsibility of college students. Through the education of international situation, we recognize that the death of the individual countries' ambition of destroying our country still exists, so a better life needs to be created by ourselves. Under the circumstances of ideology, some western countries have been suppressing the development of our country, attempting to collapse or dismember China. In the past, naval blockade had been carried out in the way of first island chain our development. Now some countries adopt "C" type encirclement to suppress China and try to beat China by fanning the flames in East China Sea and South China Sea, whose purpose is to make our country struggle to cope with the threats so that economy cannot be effectively developed so as to drag down our country. Therefore, college students should strengthen professional learning and promote the construction of the motherland from all walks of life with their own ability and cleverness, thus making some western countries' conspiracy of destroying our country be aborted.

\section{ACKNOWLEDGEMENTS}

XiangNan University Project in 2015 Research on the countermeasures of construction of study style in the transitional period of XiangNan University (2015SD05)”; Philosophy social science fund project of hunan province in 2016 "Study on Colleges and universities to carry out the shame education to enhance the College students' ideological and moral quality (16Bl3); Research project of teaching reform in colleges and universities of Hunan in 2015 "Research on the theory and practice of "double qualified teachers" construction based on school enterprise cooperation in local colleges and Universities (X.J.T. [2015] 291)

\section{REFERENCES}

[1] Chen, Y.D., 2014. Discussion on the concept, subject and characteristics of the construction of the study style in colleges and universities. Higher Education Exploration.

[2] Liu, B.H., Guo, X.L., 2011. Analysis of the style of study. Education \& Art.

[3] Zi, S., 2014. Doctrine of the Mean. Beijing Times Chinese Publishing House: Beijing.

[4] Su, B.X. 2014. On the measures and paths of the construction of study style in colleges and universities. Contemporary Vocational Education. 